\title{
Damage Detection Tool Design of Lightweight Concrete Using Optical Fiber Sensor and Phototransistor
}

\author{
Farida Asriani ${ }^{1}$, Gandjar Pamudji ${ }^{2}$, Hesti Susilawati ${ }^{3}$, Septa Wijaya Ismani ${ }^{4}$
}

\begin{abstract}
The developments in the construction of buildings, roads, and bridges commonly use concrete as the main material due to its strength and hardiness. However, the quality of the concrete may decrease due to some factors namely the age of the concrete, temperature, pressure, tension, etc. Thus, it is important to monitor its condition to find out any small damage such as cracks. Utilizing optical fiber power loss, a sensor capable of detecting cracks on a concrete can be made. This research uses multimode fiber optic planted inside the concrete. Sensor variation model being planted is in the form of wave. The lightweight concrete is designed using plastic aggregate. A specific tool capable of responding the change of the laser power coming through the fiber optic using phototransistor is also made in this research. The concrete is tested using two testing equipment at a time namely pressure testing that uses UTM (Universal Test Machine) to assess mechanical loading. Testing out the concrete using designed result tool is done by shooting laser on one side of the optical fiber and read the output power. During the test, the concrete is loaded continually and gradually increases using the UTM. The source of the light is laser, $850 \mathrm{~nm}$ of length. The result of the experiment and tool testing show that when the quality of the concrete decreases, laser power output through optical fiber increases.
\end{abstract}

Keywords- optical fiber, sensor, phototransistor, concrete, laser, arduino UNO R3, strain, tension.

\section{INTRODUCTION}

Nowadays the concrete made from lightweight aggregate as structure has been widely used. It is used for the building of constructions, bridges, and transportation facilities. Due to natural factors, they are damaged earlier than the approximate age of the building, for example the collapse of the bridges which has to be anticipated to avoid any fatalities. However, to monitor the concrete condition continuously brings its own challenge since usually the physical condition of the concrete is measured temporarily not continuously. Fortunately, the advancement in the field of instrumental science supported by the progress of IT makes it possible to observe the condition of the concrete continuously.

Design of monitoring systems for disaster mitigation has been developed to prevent casualties. One of them is the

1,3 Lecturer, Electrical Engineering, Faculty of Engineering Unsoed, Jl. Mayjen Sungkono KM. 5 Blater, Purbalingga, 53371, INDONESIA (Tlp: 0281-6596700; Fax: (0281) 6596801; email: faridapamuji@gmail.com)

${ }^{2}$ Lecturer, Civil Engineering, Faculty of Engineering Unsoed, Jl. Mayjen Sungkono KM. 5 Blater, Purbalingga, 53371, INDONESIA (Tlp: 0281-6596700; Fax: (0281) 6596801; email: gandjar_p@gmail.com)

4 Student, Electrical Engineering, Faculty of Engineering Unsoed, Jl. Mayjen Sungkono KM. 5 Blater, Purbalingga, 53371, INDONESIA (Tlp: 0281-6596700; Fax: (0281) 6596801) system of monitoring system of disaster mitigation of volcanoes [1]. The study conducted damage detection system design based on optical fiber sensor and phototransistor.

As a result of material engineering, optical fiber is widely used in the field of telecommunication technology as a transmission media or propagation of light. Optical fiber sensor can be applied as a sensor planted inside the concrete with certain configuration to sustainably measure its physical properties such as strain parameters and shifting concrete structural elements. The use of optical fiber sensor in concrete engineering is a result of the interdisciplinary science cultivation of optical fiber, optoelectronics, microelectronics, artificial intelligence, composite materials science, as well as structural engineering. However, comparing overall characteristic, optical fiber sensor has better facility and superiority than any other sensors so that it becomes the main option for sensing process of the concrete structure [2]. Distributed optical fiber sensor can be applied as planted smart structure to observe temperature, strain, and vibration of the concrete. This sensor has resolution of centimetres and a high level of precision in measuring temperature [3]. Optical fiber sensor is also applied to detect frame corrosion of the concrete [4], [5]. The technique is to coat the optical fiber with a thin iron film then implanting them in the concrete. Optical fiber sensor withstands the corrosion if used in an open structure (as bridges and dams) and is super durable which makes it possible to use over the period of the concrete. Optical fiber sensor, by utilizing its curvature, has a working principle of modulating the intensity of light which comes through an optical fiber [6].

The existence of the curvature of optical fiber cable may result in serious energy loss [7]. There is a connection between optical fibers planted in the concrete with the magnitude of the burden imposed on the concrete pressure. The higher the load imposed on the concrete, the higher the laser power losses are passed on fiber optics [8], [9]. To detect the strain and cracks in the concrete due to loading, the optical fiber has good sensitivity [8] - [10].

The utilization of optical fiber as a sensor is applied by providing laser light input on one tip of the optical fiber and detecting changes of the output on the other side. Laser or LED has been widely used as detectors, one of which is to detect the presence of an object by using visible light with specific wavelengths [11]. In this paper, a laser is used as a signal detector of damage to the concrete. Laser light propagated through the optical fiber is captured by the phototransistor in order to read or change the shape of the light signal into an electric voltage. Electric voltage is then inserted into the Arduino device that can display information about the condition of the concrete. 


\section{MethodOlOGY}

\section{A. Tools and Materials}

To carry out the research, there are some equipment and materials needed as shown in Table I.

\section{B. Methods}

In this paper, the researchers created a lightweight concrete damage detection device utilizing multimode optical fiber cable and phototransistor sensor. The principle of the detection devices is that the fiber optic cable is buried in the concrete; so that quality of the concrete can be monitored by light signals propagated in the optical fiber in the form of laser. Concrete damage can be detected with reduced output power on the optical fiber. In order to detect power reduction, phototransistor sensor is used. This phototransistor serves to convert the light signal into voltage signal. The reading of the output phototransistor is processed using the Arduino and displayed on the LCD.

TABLE I

TOOLS AND MATERIALS

\begin{tabular}{|l|l|l|l|}
\hline \multicolumn{2}{|c|}{ Tools } & \multicolumn{2}{c|}{ Materials } \\
\hline No. & \multicolumn{1}{|c|}{ Name } & No. & \multicolumn{1}{c|}{ Name } \\
\hline 1. & Ruler & 1. & Cement \\
\hline 2. & Solder & 2. & Sand \\
\hline 3. & Electric drill & 3. & Water \\
\hline 4. & Grindstone & 4. & Gravel \\
\hline 5. & Hacksaw & 5. & Optical fiber MM \\
\hline 6. & White wire & 6. & Arduino Uno R3 \\
\hline 7. & Pliers & 7. & Phototransistor sensor \\
\hline 8. & Adhesive & 8. & 16x2 character LCD \\
\hline 9. & Multimeter & 9. & Invisible laser \\
\hline 10. & Charter knive & 10. & Supporting components \\
\hline
\end{tabular}

1) Preparation of Equipment and Materials: The research activities started by preparing tools and materials to be used. All the tools and materials prepared are still functioning well.

2) Designing of Optical Fiber Sensor: Three metres of multimode optical fiber cable is stripped off of its cladding layers right in the middle of the cable. Then, configuration resembling the letter $S$ with a specific size is made using the cable as shown in Fig. 1. The stripped part of optical fiber is wrapped around the wire which has been formed "S" as shown in Fig. 1. The purpose is to maintain the shape of the optical fiber configuration when planted in the concrete.

3) Planting Fiber Optic Sensor in Concrete: Optical fiber sensors are planted in the concrete when casting. Concrete moulding size used is $15 \mathrm{~cm} \times 15 \mathrm{~cm} \times 60 \mathrm{~cm}$. The concrete is made from material composed of sand, cement, water and aggregate, with Norman quality concrete design with watercement factor of 0.42 . Concrete casting sequence is as follows: the concrete mix is put into a mould approximately 3 $\mathrm{cm}$ of height. Second, configured optical fiber sensor is planted inside the mould and continue with the filling of the cement until the mould is full. Concrete mould is opened after 24 hours and testing is done after 28 days.

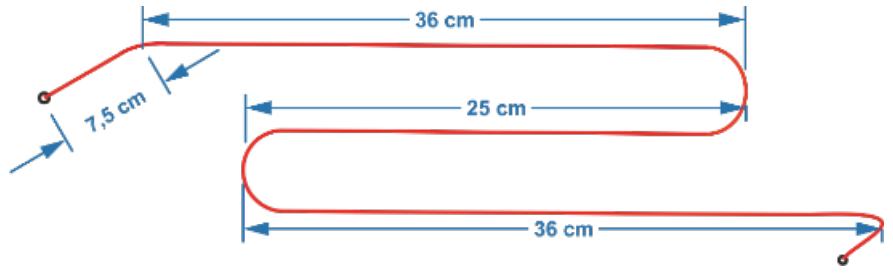

Fig. 1 Fiber with "S" configuration.

4) Adjusting Light Source, Fiber Optics and Detectors: At this stage, it is assured that the fiber optic cable, invisible laser light source and a phototransistor sensor has been connected correctly. Invisible laser as a light source used is set to have an appropriate wavelength, so that it can propagate well in the optical fiber and is accepted by the phototransistor.

5) Concrete Damage Detection Equipment Design: At this stage, a hardware configuration is made to form a unity that measures any changes in light intensity provided by the invisible laser and converts it into a voltage. The output voltage is then processed using Arduino Uno R3 and is displayed on a 16 x 2 character LCD. The measuring instrument is comprised of a series of sensors, regulator circuit, and series of buttons, Arduino, and LCD.

6) Data Collection: Data were collected by concrete testing in the laboratory. Strain gauges are placed to measure the strain of concrete. Loading of concrete is done by using a universal test machine (UTM). There are two tests performed at the same time. The first test is testing the mechanical properties of concrete, namely the stretch, using UTM and Linear Variable Differential Transformer (LVDT). At the same time, when the concrete is tested, testing is also performed to a tool by connecting one optical fiber terminal with the source of the laser while the other is connected with the designed tool. At this stage, the measured data is a strain value of the measurement results by the LVDT and the value of the output voltage generated by the designed instrument.

7) Data Analysis: Final data were analyzed to determine the sensitivity of a generated tool toward the concrete damage due to loading. Analysis was performed by graphing the strain data toward loading and strain graphic toward loading.

\section{RESULT AND DISCUSSION}

\section{A. Designing Fiber Optic Configuration}

Cladded fiber optics arranged in the "S" configuration is shown in Fig. 2. The length of the peeled jacket is $110 \mathrm{~cm}$ of total cable length of $300 \mathrm{~cm}$. Part of the peeled optical fiber is wrapped around the wire. The " $\mathrm{S}$ " design in optical fiber aims to create micro bending in every curve due to the loading so the losses in optical fiber output power can be detected. Sensitivity caused by micro bending is utilized as a sensor.

\section{B. Designing Concrete with Fiber Optic Sensor}

Configuration (as shown in Fig. 2) is then moulded in concrete as shown in Fig. 3 with optical fiber placed right in the middle. Moulding of $60 \mathrm{~cm} \times 15 \mathrm{~cm} \times 15 \mathrm{~cm}$ is used in this research. In detail, the position of the optical fiber is $3 \mathrm{~cm}$ 
from the bottom edge for the lowest position. The top sensor is positioned $3 \mathrm{~cm}$ from the top of the concrete. The left edge sensor is positioned $12 \mathrm{~cm}$ from the left end of the concrete, whereas the right edge sensor is positioned $12 \mathrm{~cm}$ from the right end of the concrete.

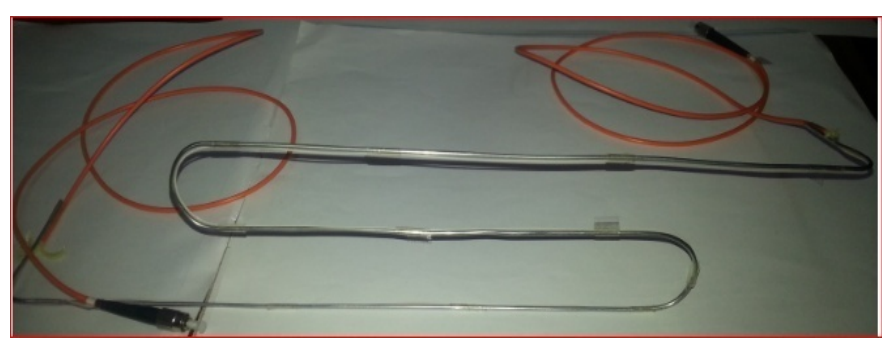

Fig. 2 Optical fiber with "S" configuration.

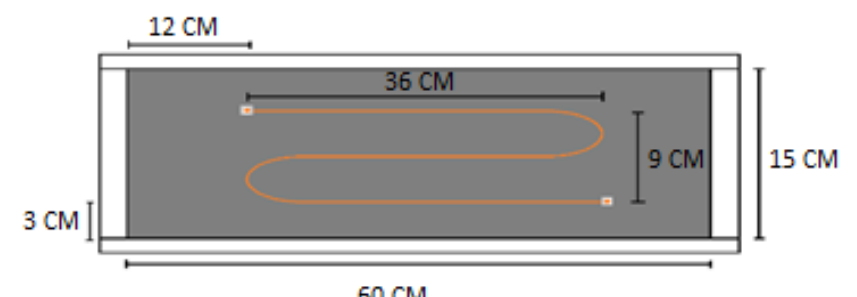

$60 \mathrm{CM}$

Fig. 3 Template position of fiber optic sensors in the concrete.

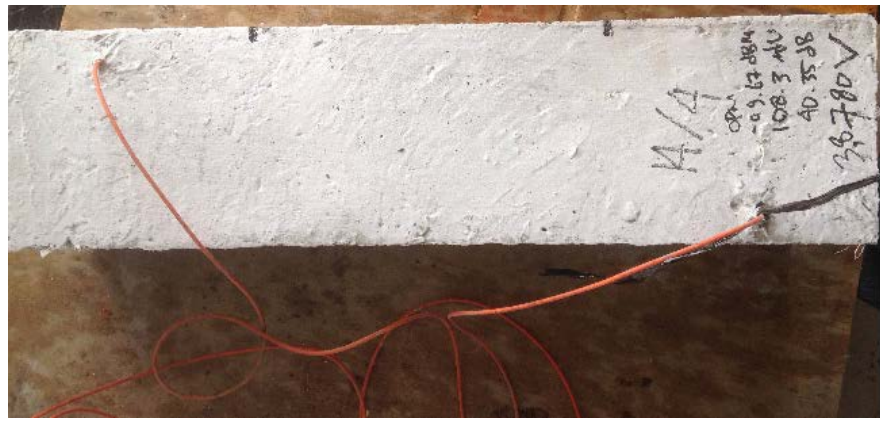

Fig. 4 Concrete with planted sensor.

Designed lightweight concrete is built with the composition of cement, sand, plastic aggregate, and water. The use of shredded plastic is to substitute gravel in order to obtain lightweight concrete. The percentage of materials of the cocrete was $22.86 \%$ cement, $39.37 \%$ sand, $26.40 \%$ plastic aggregate, and $11.37 \%$ water. Two concrete samples were made from them. The results of concrete with planted sensors are shown in Fig. 4.

\section{Designing and Testing of Electric Circuits}

In this study, an instrument is designed to detect any damage to the concrete. The principle of this tool is that if there is damage to the concrete, the tool will detect changes measured by voltage of the optical fiber sensor. Damage of the concrete is characterized by the existence of cracks inside. Physically, the concrete is declared broken if its capacity decreases.

1) Regulator Circuit: Regulator circuit (as shown in Fig. 5) is designed to use two 9-volt batteries and IC 7812. This design aims to get the tool's power supply of 12 volts and power supply for the Arduino of 5 volts.

The results of regulator testing for the power supply of the designed tool with the source of two 9-volt batteries obtained an average voltage of 11.99 volts taken from five measurements. Based on the design, the result produced by the regulator should be 12 volts. Thus, there is an error of 0.01 volt.

2) Phototransistor Sensor Circuit: Phototransistor sensor circuit scheme is shown in Fig. 6. There are three steps of testing. The first phase is done in the OFF state laser source, with the results showing the output voltage of the phototransistor is 5 volts. The second test is done in the $\mathrm{ON}$ state of laser source, with a wavelength of $850 \mathrm{~nm}$ and the output voltage of 3.7 volts. The third testing is done with the laser $\mathrm{ON}$ and the fiber optic cable was bended. The result shows the output voltage of 4.75 volts. This shows the sensitivity of the optical fiber sensor toward curvatures and phototransistor sensor sensitivity toward changes in laser power that passes through the optical fiber. Phototransistor circuits function well and are sensitive to optical fiber bending.

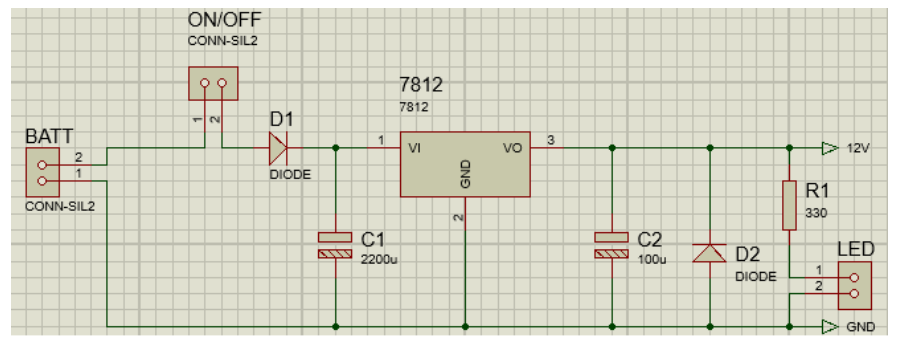

Fig. 5 Regulator circuit.

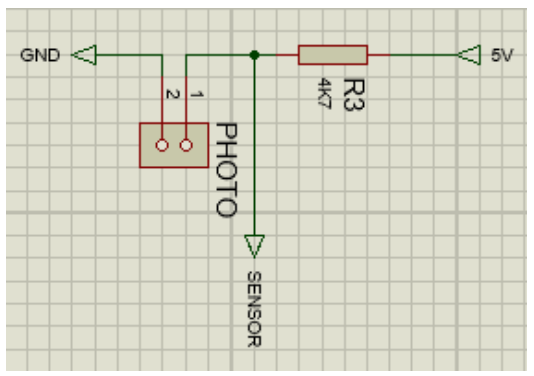

Fig. 6 Sensor circuit.

\section{Designing Concrete Damage Detection Tool}

A circuit schematic in Fig. 7 is a device that combines the design of regulator circuit, sensor circuit, a series of buttons, LCD series, and Arduino. The final design of concrete damage detection tool is shown in Fig. 8.

\section{E. Testing Equipment and Optical Fiber Sensors in Concrete}

Testing of optical fiber sensors planted in the concrete was done by testing the physical properties of concrete through destructive testing. Concrete is damaged when it begins to crack due to loading. In a good condition, the concrete compressive strength increases until its maximum threshold when the loads increase. When the limit of acceptable load 
point is reached, increasing the test load will result in concrete compressive strength decrease. In this condition, the concrete is already damaged.

In this test, the gradual and continuous loading using UTM was given to the concrete until it was damaged (cracked). All strain changes in the concrete were measured using LVDT, as shown in Fig. 9. Fiber optic sensor measurement was done using the designed tool. Since the test applied was a continuous destructive test, one concrete sample can only be done one time measurement. The results of measurements of strain due to loading changes are shown in Fig. 10 and the result of changes in the output power of the optical fiber is shown in Fig. 11.

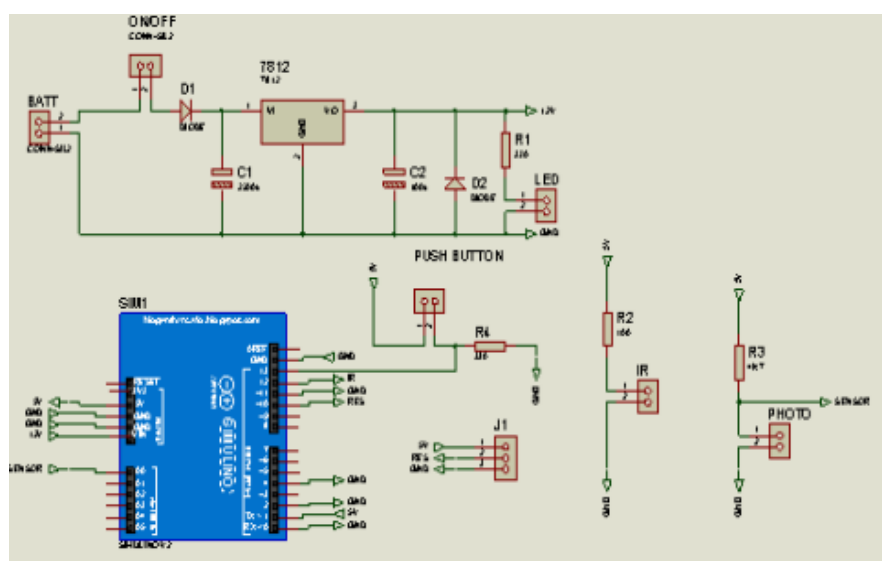

Fig. 7 The circuit schematic of the measuring instrument.

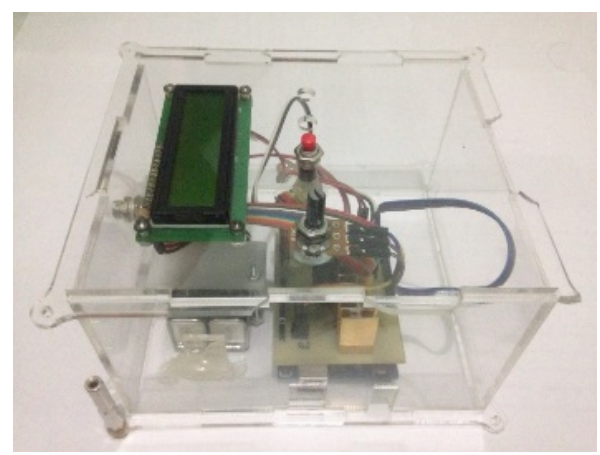

Fig. 8 The finished result of tool design.

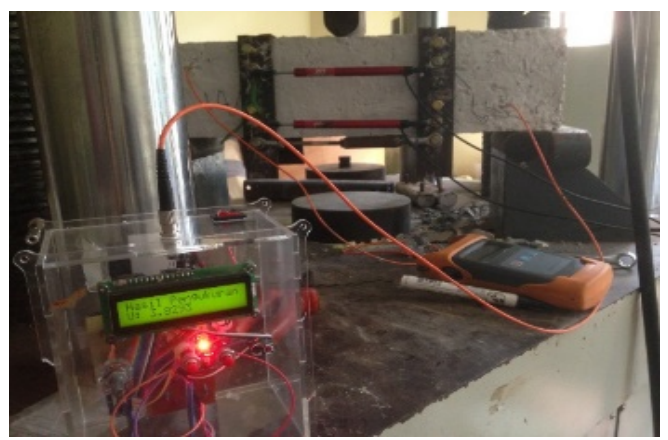

Fig. 9 Testing of concrete with UTM, LVDT, and the designed tool.

Strain is measured in millimeters. Concrete strain measurement results showed that there was an increase in the value of strain along with the increased load placed on the concrete. Being observed from graphic 0 to $4 \mathrm{kN}$, the change of strain was a bit slow. At this condition, the concrete had no crack yet. It began to crack when loading $4 \mathrm{kN}$ and got worse when the load was increased from $4 \mathrm{kN}$ to $6 \mathrm{kN}$. From the observation, the change of the strain was faster compared to when the concrete was still intact. When the load was increased for more than $6 \mathrm{kN}$, fractures occurred in concrete (as shown in Fig. 12) and strain value increased dramatically.

Results of the designed tool testing in Fig. 11 showed that when the concrete was still intact, despite an increase in the value of the load, i.e. from $0 \mathrm{kN}$ to $4 \mathrm{kN}$, the output voltage of the tool remained. When the concrete began to experience cracks, there was an increased tension in the designed tool. The tension continued to rise when the load increased. When the concrete reached a damaged condition, tension readings on the instrument indicated a drastic increase. Seeing from the comparison between Fig. 10 and Fig. 11, when the concrete began to break, changes in strain were comparable to the change in the optical fiber sensor output measured by the designed tool.

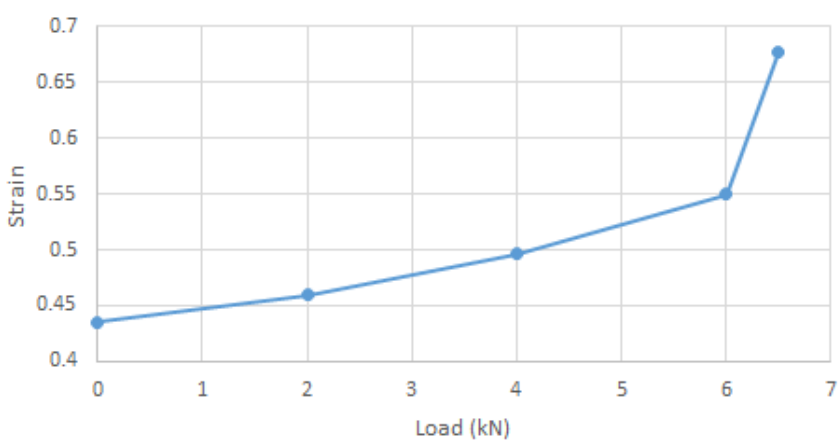

Fig. 10 Graphic relation of load and concrete strain.

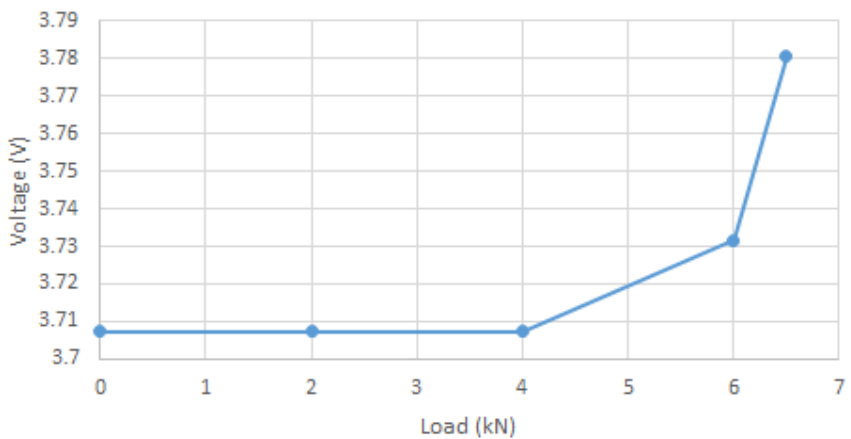

Fig. 11 Graphic relation of load and optical fiber output voltage.

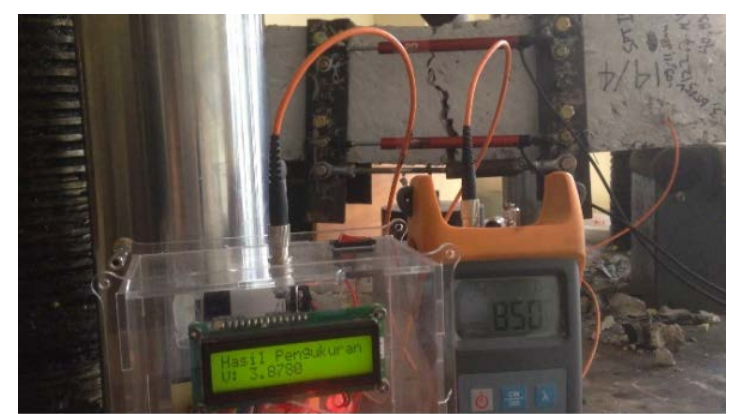

Fig. 12 The test when the concrete started to break. 


\section{F. Comparison with the Previous Research.}

Previous research has been done on the early detection of cracks of concrete using optical fiber [9]. The principle used is the ability of the fiber optic transmitting wave to the end of the detector. The loads given in the concrete varies from $1 \mathrm{~kg}$ to $15 \mathrm{~kg}$. The output of the optical fiber captured by the detector was processed in a way that made it usable to detect the presence of pressure on the concrete. Results show that compressive force given is proportional to the losses generated by the optical fiber. Differences between previous studies and this present research are shown in Table II.

TABLE II

COMPARISON WITH PREVIOUS RESEARCH

\begin{tabular}{|l|l|l|}
\hline No & \multicolumn{1}{|c|}{ Present research } & \multicolumn{1}{c|}{ Previous research } \\
\hline 1. & Using multimode fiber optic. & Using singlemode fiber optic. \\
\hline 2. & $\begin{array}{l}\text { Optical fiber configuration } \\
\text { form is "S". }\end{array}$ & $\begin{array}{l}\text { Optical fiber configuration } \\
\text { form is circle like "O”. }\end{array}$ \\
\hline 3. & $\begin{array}{l}\text { Concrete test load of 0kN - } \\
6 \mathrm{kN} .\end{array}$ & $\begin{array}{l}\text { Concrete test load of 1kg - } \\
15 \mathrm{~kg} .\end{array}$ \\
\hline 4. & $\begin{array}{l}\text { Comparing the results of } \\
\text { measurement of output } \\
\text { tension with the } \\
\text { measurement results of } \\
\text { mechanical properties of } \\
\text { concrete as a result due to the } \\
\text { loading. }\end{array}$ & $\begin{array}{l}\text { Measure the losses (in } \mathrm{dB} \text { ) as } \\
\text { result of the loading. }\end{array}$ \\
\hline 5. & $\begin{array}{l}\text { Discussing the results of } \\
\text { stress and strain changes in } \\
\text { the concrete when the } \\
\text { concrete begins to crack. }\end{array}$ \\
\hline
\end{tabular}

\section{CONCLUSIONS}

In conclusion, fiber optics can be used as a sensor detecting the damage to the concrete. The damage occurs in concrete indicated by a change in the output power of the optical fiber. Phototransistor sensor has a good sensitivity toward changes in the output power of the optical fiber. Concrete with designed planted sensors indicated cracking when given a load of $4 \mathrm{kN}$, and began to fracture when given a load of $6 \mathrm{kN}$. The result of the designed concrete damage detection device can work out properly by providing a signal tension which increases quite dramatically when the concrete starts to break.

\section{ACKNOWLEDGEMENT}

The authors would like to express their gratitude to the Ministry of Research, Technology and Higher Education of the Republic of Indonesia that provided financial support through grants so that this research could be conducted and the Rector of Universitas Jenderal Soedirman Purwokerto Central Java who provided facilities and infrastructure so that this research could be done well.

\section{REFERENCES}

[1] Pamungkas J. and Wirawan, "Desain Real Time Monitorring Berbasios Wireless Sensor Network Upaya Mitigasi Bencana Erupsi Gunungapi”, JNTETI, vol 4, no 3, 2015.

[2] Mousumi Majumder, Tarun Kumar Gangopadhyay, Ashim Kumar Chakraborty, Kamal Dasgupta, D.K. Bhattacharya, "Fiber Bragg gratings in structural health monitoring-Present status and applications”. Sensors and Actuators A, Vol. 147, pp 150-164, 2008.

[3] Bao, X. and Chen, L., "Development of the Distributed Brillouin Sensors for Health Monitoring of Civil Structures. In Optical Waveguide Sensing and Imaging”, NATO Science for Peace and Security Series B: Physics and Biophysics; Springer: New York, NY, USA, pp. 101-125, 2008.

[4] Sidek o, Kabir S., and Hassan M bin Afzal, "Fiber Optic Based Sensing Approach for Corrotion Detection”, Proceeding of PIERS, Suzhou, China, 2011.

[5] Leung Christopher K.Y., Wan Kai Tai, and Chen Liquan, “A Novel Optical Fiber fot Steel Corrotion in Concrete Structure”, Sensors, 8, pp 1960-1976, 2008.

[6] Yu, F. T., and Yin, S, Fiber Optic Sensor, New York: Marcel Dekker, Inc, 2008.

[7] Crisp, J., and Elliott, B., Serat Optik Sebuah Pengantar, Jakarta: Erlangga.

[8] Asriani F, Pamudji G and Susilawati H, "Pengembangan Deteksi Kerusakan Beton yang Menggunakan Agregat Sampah Plastik dengan Sensor Fiber Optik Tertanam”, Prosiding Seminar Nasional Ketekniksipilan Bidang Vokasional III, pp 69-73. Bali, September 2015,

[9] Asriani F, Pamudji G and Susilawati H, "Fiber Optic Singlemode Sebagai Sensor Regangan yang Tertanam di dalam Beton”, Prosiding Jilid 1 SNTT 2016, pp 45-50, November 2016,

[10] Sujito and Putra Billy Sptian,” Deteksi Dini Kerusakan Konstruksi Beton Menggunakan Fiber Optik SMF-28”, Simposium Fisika Nasional XXVI, pp 275-281 Malang, 2013,

[11] Pinandita, S., "Rancang Bangun Alat Pengendali Hama Wereng Mekanik Menggunakan LED dan Alat Penyedot”, JNTETI, vol. 3 no. 4 pp. 281-286, 2014. 